\title{
Bacterial bioremediation: Strategies adopted by microbial- community to remediate lead from the environment
}

\author{
Afreen Shahid ${ }^{1}$, Chitranshu Pandey ${ }^{2}$, Farhan Ahmad ${ }^{3}$ (D), Aisha Kamal ${ }^{4 *}$ (D) \\ ${ }^{1}$ Department of Biosciences, Integral University, Lucknow, India. \\ ${ }^{2}$ Department of Biotechnology, Sri Ram Swaroop Memorial University, Lucknow, India. \\ ${ }^{3}$ Department of Biotechnology, Ashoka Institute of Technology and Management, (affiliated to Dr. A.P.J. Abdul Kalam Technical University, Lucknow), \\ Varanasi, India. \\ ${ }^{4}$ Department of Bioengineering, Integral University, Lucknow, India.
}

\begin{tabular}{l}
\hline ARTICLE INFO \\
\hline Article history: \\
Received on: April 21, 2021 \\
Accepted on: July 16, 2021 \\
Available online: November 10, 2021 \\
\hline
\end{tabular}

Key words:

Lead toxicity, lead resistant bacteria, encapsulation, bacterial biosensors

\begin{abstract}
Excessive lead accumulation is a severe concern for the environment as its toxicity is associated with soil microbial diversity, agricultural production, and human health. Physico-chemical methods of remediation of lead from the existing environment are generally costly and also not efficient due to the production of another form of the toxic compound. Bioremediation has been now considered the most efficient method to remove heavy metals from the surrounding by using microorganisms and plants. Microbes are generally more resistant than any eukaryotic organism and act as a key player in mitigating lead toxicity. The absorption and accumulation of toxic metals by bacteria exhibit many metabolically related and independent processes. Biotransformation, biosorption, precipitation, and encapsulation are the most efficient strategies opted by the microbial system to remediate lead metal from wide sources such as soil, sludge, and wastewaters to clean the environment. Genetically improved bacterial strains have good efficiency and have multiple modes of remediation from soil and other industrial waste. However, environmental biotechnology has not yet explored many aspects of the interaction between metals and microorganisms, and further development and applications are needed to deliver the non-toxic form of lead into the ecosystem. This review also highlights the potential of lead-resistant bacteria used as a biosensor for lead contamination sites.
\end{abstract}

\section{INTRODUCTION}

Water, air, and land (fertile soil), which are extremely important for life, have been made impure by exposure to heavy metals owing to the constantly rising population, rapid industrialization, and urbanization [1]. The groups of elements having a density of more than $7 \mathrm{~g} \mathrm{~cm}^{-3}$ have been regarded as heavy metals and mainly include lead, cadmium, arsenic, copper, chromium, silver, zinc, and many others. Among all, lead $(\mathrm{Pb})$ is one of the most pervasive as well as most toxic element documented for severe health issues and environmental concern and is regarded as the chemical of great concern [2]. In addition to natural and human activities, mining, refining, coal, industrial wastes, arsenic-rich pesticides, toxic

\footnotetext{
*Corresponding Author

Aisha Kamal, Department of Bioengineering, Integral University, Lucknow, India.E-mail: aishakaml04@gmail.com
}

chemical fertilizers also increased the lead contamination in the environment [3]. Lead usually exists in the soil as ionic lead (for example, $\mathrm{Pb}(\mathrm{II})$ in the form of $\mathrm{PbSO} 4$ ) oxides and hydroxides, and metallic lead-oxygen anion complexes [4]. Phosphates, carbonates (above pH 6), hydroxides/oxides, sulfides, and pyromorphites are some of the most stable and insoluble forms in which lead is found in soils with a wide $\mathrm{pH}$ range. Lead adsorption is a sequential process and its accumulation in soil occurs in various forms such as free metal ions, complex metal components, or organic acids (amino acid, humic acids) depending upon bioavailability, mobility, and toxicity [5]. Due to strong bonds with organic and colloidal substances, a small amount of lead dissolves in the soil and can be used by plants for absorption [6]. Lead usually does not play a beneficial role in biological systems and is harmful to plants, animals, and human health. Higher accumulations of lead generate oxidative stress resulted in cellular halt and thus inhibiting seed growth, cell divisions, pigments productions, 
and delayed flowering $[7,8]$. In humans, lead toxicity affects the nervous system and causes cardiovascular diseases, renal failure, and reproductive disorders [9]. Severity of lead toxicity depends upon dose and duration of exposure; mode of consumption, for example, uptake of lead contaminated water or foods or directly inhaled from environments. Long-term exposure showed vision and memory loss, muscle and joint pains, intolerance to food allergens and gastrointestinal disorders. Lead contamination also causes biological expansion at various tropical levels of the food chain [10]. Lead is also toxic to natural biota, including altering microbial diversity and distribution [11].

As lead contamination becomes widespread, there is an increasing interest in recovering or reducing lead concentrations in soil. Cheap and efficient technologies must be used to repair leadcontaminated sites for efficient distribution [12]. Bioremediation is an advanced and eco-friendly method for recovery and lead removal from contaminated areas. Indigenous and exogenous living organisms especially microorganisms and plants are indulged to recover or reduce lead into less hazardous forms. More recently, phytoremediation and mobilization and washing of lead-contaminated soil with metal chelators have been widely used. These methods often replace chemical and physical methods that use non-recyclable materials and add to the cost of subsequent processing. In addition, this process leads to the formation of a large amount of secondary waste and is not environmentally friendly [13]. Microorganisms play an important role in attracting and converting the lead. Strains with this unique ability can effectively reduce lead contamination by employing a variety of defense mechanisms to keep lead levels low without compromising development or metabolism that are given in Table 1. Since bacteria are more resilient than any other eukaryotes, the use of bacterial strains to restore the environment is mainly focused on realizing their heavy metal recovery potential in terrestrial and aquatic ecosystems. This review focuses on the bacterial system, especially the current understanding of the various mechanisms of bacterial lead resistance, as well as methods and strategies for removing lead from the environment.

\section{MICROBIAL SYSTEM AND LEAD DETOXIFICATIONS MECHANISMS}

It was earlier reported that accumulations of lead pollutants significantly reduced the microbial diversity and distribution while soil fertility is completely dependent upon the microbial diversity (enzymatic form) those catalyzes enzymatic reactions essentials for both plants and microorganisms [2]. Lead toxicity to microorganisms causes cell membrane destruction, nucleic acid degradations, protein denaturation resulted in lowering enzymatic activity, cellular division, and metabolic respiration thus consequently results in death $[14,15]$. Survival strategies for bacteria in areas contaminated with lead include the deposition of metals such as phosphates, carbonates, and sulfides, accumulation in cells, siderophores on cell surfaces or extracellular polymers, and attachment to living organisms including absorption $[13,16]$.

The complex mechanisms of the microbial system include physicochemical mechanisms such as electrostatic interaction, ion exchange, precipitation, redox mechanism, and complexity [17]. Mechanical resistance to heavy metals by microorganisms include metal oxidation, methylation, enzymatic destruction, organometallic damage, metal degradation, metal-ligand destruction, metal removal, demethylation, and chelation of metals inside and outside the cell, by permeability inhibition and production of metal chelators (such as metallothionein and bioactive compounds) [18]. Due to the existence of an anionic system, this allows microorganisms to bind to metal cations, microorganisms carry a negative charge on the cell surface [6]. The main constituents of microorganisms associated with the adsorption of metals are hydroxyl, alcohol, phosphoryl, amine, carboxyl, ester, sulfhydryl, sulfonate, thioether, and thiol groups [19].

Table 1: Lead resistant bacteria and their methods to resist lead.

\begin{tabular}{cccc} 
S.N. & Bacteria & Methods/process & References \\
$\mathbf{1}$ & P. aeruginosa ASU6a & Biosorption & {$[22]$} \\
$\mathbf{2}$ & Oceanobacillus profundus & Biosorption & {$[23]$} \\
$\mathbf{3}$ & Klebsiella sp. 3S1 & Biosorption & {$[24]$} \\
$\mathbf{4}$ & Pseudomonas pseudoalcaligenes & Biosorption & {$[26]$} \\
$\mathbf{5}$ & Micrococcus luteus & Biosorption & {$[26]$} \\
$\mathbf{6}$ & Strains (Q3 and Q5) of Bacillus sp. & Biosorption & {$[11]$} \\
$\mathbf{7}$ & Gloeocapsa gelatinosa & Bioaccumulation & {$[27]$} \\
$\mathbf{8}$ & Bacillus cereus & Bioaccumulation & {$[28]$} \\
$\mathbf{9}$ & B. megaterium & Bioaccumulation & {$[29]$} \\
$\mathbf{1 0}$ & Bacillus cereus RPb5-3 & Bioaccumulation & {$[30]$} \\
$\mathbf{1 1}$ & P. vermicola strain SJ2A & Bioaccumulation & {$[31]$} \\
$\mathbf{1 2}$ & Providencia alcalifaciens $2 E A$ & Precipitation & {$[32]$} \\
$\mathbf{1 3}$ & Penicillium chrysogenum CS1 & Precipitation & {$[33]$} \\
$\mathbf{1 4}$ & V. harveyi & Precipitation & {$[34]$} \\
$\mathbf{1 5}$ & E. cloacae & Precipitation & {$[35]$} \\
\hline
\end{tabular}




\subsection{Biosorption on Cell Surface}

Plasma particles, cell walls, or microbial capsules can prevent ions from entering the cell. Bacteria can form metallic ions from a variety of ionizable compounds (amino, carboxyl, phosphate, and hydroxyl) on cell walls [20]. There are several important points on the cell wall of Gram-positive bacteria that can bind metal cations, and phosphate groups play an important role in the binding of metals in Gram-negative bacteria [21]. The carboxyl, phosphate, hydroxyl, and amino groups on the cell wall of Pseudomonas aeruginosa ASU6a are responsible for the fixation of $\mathrm{Pb}(\mathrm{II})$, while the amide, amino, hydroxyl, or carboxyl group on the $\mathrm{Pb}^{2+}$ bond on the cell wall of Synechococcus sp. are involved in [22,23]. In Escherichia coli, most of the lead $\left(\mathrm{Pb}^{2+}\right)$ is bound to the cell membrane, the cell wall of peptidoglycan has no binding affinity [24]. In the genus Bacillus ATS-2, carboxyl and hydroxyl groups, and amide and sulfonamide are all involved in the binding of $\mathrm{Pb}$ (II) [25]. The phosphate group in Saccharomyces cerevisiae is responsible for the fixation of $\mathrm{Pb}(\mathrm{II})$ [25]. The potency of $\mathrm{Pb}^{2+}$ over the cells depends on the $\mathrm{pH}$ value at the initial input. The effect of $\mathrm{pH}$ on the removal of metals (such as lead) by Pseudomonas pseudocyaninea and Micrococcus chrysogenum shows that the biosorption of metals increases when the $\mathrm{pH}$ increases from 2 to 6 , and has the strongest potential at $\mathrm{pH} 5$ [26].

\subsection{Biosorption Through Extracellular Polymeric Substances (EPS)}

Depending upon bioavailability and solubility, heavy metals easily diffuse across the cell membrane and induced toxicity [36]. To counter this phenomenon, some metal-tolerant bacteria initiate bioabsorption by secreting EPS. EPS is a high molecular weight heterogeneous mixture of proteins, humic acids, sugars, and nucleic acids. It binds to cationic metals with different specificity and affinity [37]. EPS composition depends mainly on bacterial growth, in which case more lead swelling was observed during stagnation due to the high net sugar concentration in EPS [38]. The limit cycle restores metals and prevents harmful cationic metals from entering cells. $\mathrm{Pb}^{2+}$ EPS limitation has been observed in some lead-resistant microscopic organisms [39,40]. Various factors affect the corrosion of metals by EPS, including metallic fixation, $\mathrm{pH}$, and sodium chloride focus on anti-corrosion $\left(\mathrm{Pb}^{2+}\right)$. The enzymatic EPS system also contributes to the purification of metals by conversion and degradation to polymer, making them ideal biosorbent agents for bioremediation.

In addition, to determine the role of EPS as an important factor in the biological purification of heavy metals, the cation-binding capacity of EPS from activated sludge of biofilms and biological granules was investigated [41]. The binding of metal to EPS
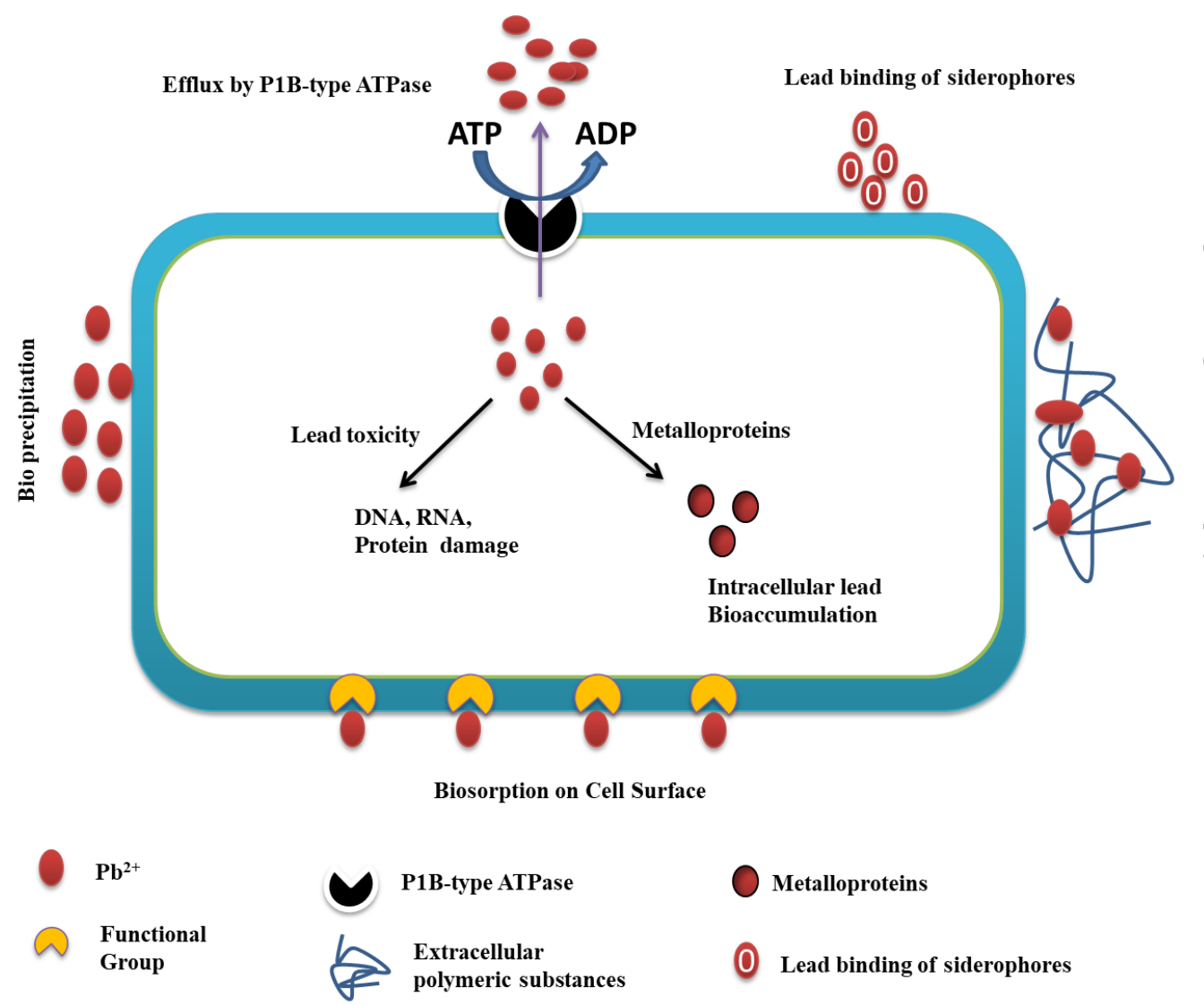

Metalloproteins

0 Lead binding of siderophores

Figure 1: Lead tolerance strategies opted by bacteria: cell surface adsorption of lead, Extracellular lead sequestration, ATPase PIB-type efflux of lead, intracellular bioaccumulation of lead, precipitation, lead binding of siderophores. 
biofilm depends on the $\mathrm{pH}$ of the environment, the concentration of the metal, the presence of organic matter and protein $(C / P$ ratio) to remove heavy metals from biomass and wastewater. In Burkholderia cepacia biofilm, $90 \%$ of the total lead uptake occurs at $\mathrm{pH}<4.5$, after which nanosized crystals of pyromorphite $\left(\mathrm{Pb}_{5}\left[\mathrm{PO}_{4}\right]_{3}[\mathrm{OH}]\right)$ accumulate in the biofilm. Activated sludge is always a rich source of various types of metal-resistant bacteria. EPS sludge has greater metallic complexity than pure bacterial culture [43]. The bioabsorption capacity of $\mathrm{Pb}^{2+}$, a bioreactor with activated sludge, is higher than that of $\mathrm{Cu}^{2+}[44]$. Anaerobic raw granules obtained from sewage sludge have also proven to be an effective biosorbent for removing $\mathrm{Pb}^{2+}$ from metal-contaminated wastewater [45].

\subsection{Role of Metalloproteins in Bioaccumulation}

Bioaccumulation is an energy driven intracellular immobilization of heavy metals with the additional help of low molecular proteins known as metalloproteins [46]. Bacterial strain with lead resistance system initiates the synthesis of metallothioneins upon higher exposure of lead toxicity. This phenomenon was reported in several bacterial species (Bacillus megaterium, Proteus penneri GM-10, Providencia vermicola strain SJ2A, P. aeruginosa strainWI-1, Salmonella choleraesuis, and Streptomyces sp., 4A [28,29,31]. In the bacterial system, the presence of genomic DNA metal-binding metallothionein genes such as bmtA and smtAB may be attributed to the intracellular sequestration of lead and reduced toxicity. Genetically engineered to increase the expression of genes for resistance to lead, bacteria, or this metal-producing strain can be a powerful tool for the biological purification of lead in contaminated areas of the environment.

\subsection{Outflow Mechanism}

To control the homeostasis of lead nitrate, the concentration of lead ions inside the cell has to be firmly regulated [47]. The P1B type ATPases is a transporter protein that transports lead nitrate from outside the cell membrane and controls lead nitrate resistance $[48,49]$. Such transporter proteins stop the aggregation of high concentrations of highly aconitic and reactionary metal ions like $\mathrm{Cu}^{2+}, \mathrm{Pb}^{2+}, \mathrm{Ag}^{2+}, \mathrm{Zn}^{2+}$, and $\mathrm{Cd}^{2+}$, etc. There are two subgroups of P1B ATPases: (I) $\mathrm{Cu} / \mathrm{Ag}$ translocating ATPases encrypted in Helicobacter pylori, Enterococcus hirae, and E. coli by the cop A gene., (II) $\mathrm{Cd} / \mathrm{Pb} / \mathrm{Zn}$-ATPase codified by the ZntA gene in $E$. coli \& Staphylococcus aureus plasmid by gene cadA $[48,49]$. Multifarious PIB-type ATPases are appertaining with jumping DNA elements \& lead tolerance through the plasmid-mediated has been noticed for Ralstonia metallidurans and S. aureus [50]. The transcribed part of the genome, that encrypting PIB ATPases is noticed in most sequenced archael and bacterial genomes [51]. P-type ATPases relate to transmembrane transporters family mediated for the flow of organic molecules and ions out and in of cell membranes-type, ATPases relates to the transmembrane transporters family accountable for transfers of tiny organic molecule \& ions out and in of the cell membranes. The subclass of membrane-embedded transporter protein, which involves PIBtype ATPases, controls the outflow of lead nitrate outside the cell membranes and hinders the over-accumulation of toxic and high reactive soft metals, and like this, it gives its importance in lead resistance [51]. The transcribable part of DNA cad A, zntA, and
pbrA codes ATPase are parts of the super-family of P-type cation transporting ATPases, but relates to the category of soft metal transporters. Cation diffusion facilitator and P-types ATPases transporters transport lead ions from cytoplasm to periplasm while carbohydrate-binding agents, a trans-membrane envelope efflux pump, play a role of chemiosmotic ion-proton exchanger to remove periplasmic lead ions [52].

\subsection{Bio Precipitation}

For reductions of toxicity and bioavailability, precipitation is mostly adopted by bacterial systems to convert soluble metal into an insoluble form. The precipitation process occurs outside (extracellularly) or inside (intracellularly) the cell [33]. The lead precipitation on Citrobacter $s p$. cell surface as $\mathrm{PbHPO} 4$ that was explored by electron microscope and X-ray microanalysis although implied precipitation and accumulation of $\mathrm{Pb} 3(\mathrm{PO} 4) 2$ inside the cell of $S$. aureus cultured in the existence of huge concentration of soluble lead nitrate [53]. Similarly, Vibrio harveyi has also the potential for precipitating lead as a different phosphate i.e. $\mathrm{Pb} 9(\mathrm{PO} 4) 6$ [34]. Also, phosphate solubilizing bacterium, Enterobacter cloacae, is found to resist lead by immobilizing lead as insoluble lead phosphate, pyromorphite [35]. Besides this, microbially induced calcium carbonate precipitation techniques along with Pararhodobacter $s p$. were used to remediate the lead-contaminated sites [54]. Furthermore, ureolytic bacteria (Rhodobacter spharoides, Sporosarcina pasteurii, and Terrabacter tumescens) can proficiently hydrolyze urea to generate carbonate ions and elevate the $\mathrm{pH}$ to alkaline conditions (8.0-9.1), which promotes the precipitation of lead and calcium carbonate $[55,56]$.

\subsection{Lead-Binding Efficiency of Siderophores}

The ability of siderophores to reduce the movement of living organisms and the environment by creating complex-ligand compounds makes them an effective biodegradable system. Active siderophores are called disinfectants and are eliminated by microorganisms and act as mediators of the transport of iron to cells. Synthetic $P$. aeruginosa are pyoverdin and Pyochelin, which help to chelate $\mathrm{Fe}^{3+}$ [57]. Metal chaperones are specific to iron and can integrate well with other metals outside the cell [58]. It has also been reported that brown pigments from lead-resistant strains of Pseudomonas vesicularis and streptomycin are synthesized in the presence of lead. [59]. Similar results have also been reported, which can improve siderophores in anti-bacterial strains after application of the optimal concentration of lead nitrate.

\subsection{Bacterial Encapsulation}

Bacterial encapsulation has been considered the most efficient technique for the bioremediation of heavy metals through microorganisms [60]. Most encapsulation techniques involved spray drying, emulsifying-crosslinking, and coacervation which are based upon high temperature or organic agents that lead to potential toxicity and nutrient destructions [61]. To overcome these problems, electrospun cyclodextrin fibers (CDF) encapsulate bacteria for efficient bioremediation. CD-F not only serves as a carrier matrix but also serves as a feeding source for the encapsulated bacteria. Recently, electrospun cellulose acetate (ethylene oxide), a nanofibrous membrane were used to immobilize Bacillus paramycoides from industrial wastewater 
Shahid et al.: Journal of Applied Biology \& Biotechnology 2021;9(06):18-24

using DMSO (dimethylsulfoxide) as a solvent [62]. Celebioglu et al. [63] also reported that nanofibrous poly-CD membrane successfully removed several polycyclic aromatic hydrocarbons and heavy metals such as i.e., $\mathrm{Pb}^{2+}, \mathrm{Ni}^{2+}, \mathrm{Mn}^{2+}, \mathrm{Cd}^{2+}, \mathrm{Zn}^{2+}, \mathrm{Cu}^{2+}$ with the different sorption capacities from industrial wastewater.

\section{MICROBIAL GENETIC ENGINEERING FOR ENHANCED LEAD DETOXIFICATIONS}

With advanced genetic engineering technologies, newly developed or manipulated microorganisms can tolerate the high accumulation of metal stress, enhanced expression of metalchelating proteins and peptides, and the ability to accumulate metals [64]. Genetically improved bacteria showing the huge number of bacteria-metallothionein (BmtA) may be used to clean up environmental areas that are extremely polluted with $\mathrm{Pb}$. Bacteria may be improved by genetic engineering to express increase binding ligands i.e. sulfate, hydroxyl, carboxyl, phosphate for a huge level of toxic lead biosorption on the surface of bacterial cells. For example, for field samples, the genetically modified Campylobacter crescentiformis strain JS4022/p723-6H, which is highly expressed on the surface of bacterial cells with hexahistidine peptides, has been studied. Compared to the control strain, the high concentration of cadmium effectively sequesters combined many times [65]. By further engineering the $E$. coli cell surface to display the single binding protein PbrR, lead can be selectively adsorbed and fixed in solutions containing multiple heavy metal ions by increasing the interaction between cell surface proteins and metal ions in the environment [66]. In the laboratory, some naturally occurring metal-binding proteins and new metalchelating peptides have been designed and introduced into the bacterial system. For example, construction of E. coli BL21 (DE3) by transfer of metallothionein from Corynebacterium glutamicum C.gMT resulted in significantly higher levels of $\mathrm{Pb}^{2+}$ and $\mathrm{Zn}^{2+}$ than non-constructed E. coli BL21 (DE3) [66].

\section{BACTERIAL BIOSENSORS FOR MONITORING OF LEAD CONTAMINATION}

Bacterial bio-reporters are living microorganisms that can provide measurable results when detecting target chemical substances. Various whole-cell bacterial bioreceptors have been cultivated, and they can be used as acceptable biological devices to monitor and measure the bioavailability of lead contaminants in environmental samples with great precision, sensitivity, and specificity. It was found that the detection limit of bacterial bioinformation providers had improved when testing the presence of metals host bacterial transport system [52]. The monitoring limit of the $\mathrm{Pb} / \mathrm{Cd} / \mathrm{Zn}$ bioreporter based on Pseudomonas putida KT2440 is increased by 45 times by destroying the four main $\mathrm{Pb} / \mathrm{Zn} / \mathrm{Cd}$ drainage conveyors by forming metals for assembly in the battery. The bioreceptor can also be replaced by replacing the sensor element. The Z-specific biological receptor is generated using the $P$. putida cadA1 promoter as a sensory element. The defective engineering vector corresponding to the strain of $P$. putida stained $\mathrm{Zn}^{2+}$ ions usually 50 times less than other available $\mathrm{Zn}^{2+}$ biological reports. The detection limit of these biological reporters must be lower than the acceptable limit of $\mathrm{Pb}$ and $\mathrm{Zn}$ in soil and water. R's major protein PbrR691Metal Durans CHC34, lead (II) handcuffs can detect metal ions, such as cadmium (II), mercury (II), cobalt (II), nickel (II), and copper (I) [67]. In addition to the fact that many bioinformatics implementations have been developed to quantify heavy metals, the environmental sample requirements are still low.

\section{CONCLUSION AND FUTURE PROSPECTIVE}

Lead is an endless environmental adulterant that is deliberately assembled and contributing to bio-magnification at various trophic levels in the chain of food and gives rise to many toxic impacts on organisms. Adulterants from industries comprising a significant concentration of poisonous $\mathrm{Pb}$ that is of consequential natural apprehension should be eliminated from the adulterant sources. Physicochemical techniques like precipitation, flocculants coagulant, other used techniques are expensive, less effective, and cannot work as efficiently to remove lead heavy metals from a very low level of heavy metals. The major application of bioremediation of heavy metal polluted areas employing bacteria is the treatment of the huge amount of effluents with a low concentration of heavy metals, and it is also cost-effective because bacteria can be grown on simple media. Steps taken to achieve the bioremediation are very economical, ecological, and are very coherent as a contrast to physiochemical strategies for the elimination of lead from adulterantcontaining environmental areas. In recent decades, the effort has been directed towards exploring bacterial bioremediation of lead. In this review, various methods adopted by lead resistant bacteria such as outflow mechanism, biosorption, precipitation etc, to remediated lead contaminated environments has been discussed. Furthermore, bioremediation efficiency of living organisms by overcoming the lead toxicity and proves its suitability over conventional methods. An important feature that is already present in some bacteria may be modified by employing normal approaches to genetic engineering. Capable lead-resistant bacteria can be genetically improved in excessive production of metallothionein, and biosurfactants, and proteins would be good approaches for the clean up the lead from industrial effluents. In addition, this molecular technology allows the creation of strains with specific metal-binding properties through the expression of peptides that chelate proteins and metals. This further enhances the processes of bioadsorption and deposition of lead and introduces actions to convert the metal into robust strains. Other techniques include engineering one or an operon, modifying existing genes, and analyzing pathways to improve molecular refinement processes. Unfortunately, after excessive effort with advanced technologies, a higher level of lead in the environment is still an alarming signal there is an urgent demand for novel approaches that should be highly efficient, less costly, and more eco-friendly.

\section{ACKNOWLEDGMENT}

The authors are thankful to Dean Research and Development Committee, Integral University for allotting manuscript number (IU/R\&D/2021-MCN0001090).

\section{AUTHOR CONTRIBUTIONS}

All authors made substantial contributions to conception and design, acquisition of data, or analysis and interpretation of data; took part in drafting the article or revising it critically for important intellectual content; agreed to submit to the current journal; gave final approval of the version to be published; and 
agree to be accountable for all aspects of the work. All the authors are eligible to be an author as per the international committee of medical journal editors (ICMJE) requirements/guidelines.

\section{CONFLICTS OF INTEREST}

None.

\section{ETHICAL APPROVALS}

Not applicable.

\section{REFERENCES}

1. Li Fi. Heavy metal in urban soil: health risk assessment and management. In: Saleh HEM, Aglan RF (eds.). Heavy metals, IntechOpen, 2018; Available via https://www.intechopen.com/ chapters $/ 58942$

2. Kushwaha A, Hans N, Kumar S, Rani R. A critical review on speciation, mobilization and toxicity of lead in soil-microbe-plant system and bioremediation strategies. Ecotoxicol Environ Saf 2018;147:1035-45.

3. Rigoletto M, Calza P, Gaggero E, Malandrino M, Fabbri D. Bioremediation methods for the recovery of lead-contaminated soils: a review. Appl Sci 2020;10(10):3528.

4. Wuana RA, Okieimen FE. Heavy metals in contaminated soils: a review of sources, chemistry, risks and best available strategies for remediation. Int Sch Res Notices 2011;2011:20.

5. Norini MP, Thouin H, Miard F, Battaglia-Brunet F, Gautret P, Guégan $\mathrm{R}$, et al. Mobility of $\mathrm{Pb}, \mathrm{Zn}, \mathrm{Ba}, \mathrm{As}$ and $\mathrm{Cd}$ toward soil pore water and plants (willow and ryegrass) from a mine soil amended with biochar. J Environ Manage 2019;232:117-30.

6. Punamiya P, Datta R, Sarkar D, Barber S, Patel M, Das P. Symbiotic role of Glomus mosseae in phytoextraction of lead in vetiver grass [Chrysopogon zizanioides (L.)]. J Hazard Mater 2010;177(1-3):465-74.

7. Malar S, Vikram SS, Favas PJ, Perumal V. Lead heavy metal toxicity induced changes on growth and antioxidative enzymes level in water hyacinths [Eichhornia crassipes (Mart.)]. Bot Stud 2016;55(1):1-1.

8. Ahmad F, Singh A, Kamal A. Salicylic acid-mediated defense mechanisms to abiotic stress tolerance. In: Khan MIR, Reddy PS, Ferrante A, Khan NA (eds.). Plant signaling molecules, Woodhead Publishing, Cambridge, UK, pp 355-69, 2019

9. Kumar A, Kumar A, M M S CP, Chaturvedi AK, Shabnam AA, Subrahmanyam G, et al. Lead toxicity: health hazards, influence on food chain, and sustainable remediation approaches. Int J Environ Res Public Health 2020;17(7):2179.

10. Kundu D, Mondal S, Dutta D, Haque S, Ghosh AR. Accumulation and contamination of lead in different trophic levels of food chain in sewage-fed East Kolkata Wetland, West Bengal, India. Int J Env Tech Sci 2016;2:61-8.

11. Heidari P, Panico A. Sorption mechanism and optimization study for the bioremediation of $\mathrm{Pb}$ (II) and $\mathrm{Cd}$ (II) contamination by two novel isolated strains Q3 and Q5 of Bacillus sp. Int J Environ Res Public Health 2020;(11):4059.

12. Fernandez PM, Vinarta SC, Bernal AR, Cruz EL, Figueroa LI. Bioremediation strategies for chromium removal: current research, scale-up approach and future perspectives. Chemosphere 2018;208:139-48

13. Tiquia-Arashiro SM. Lead absorption mechanisms in bacteria as strategies for lead bioremediation. Appl Microbiol Biotechnol 2018;102(13):5437-44.

14. Khandaker MM, Abdullahi UA, Elyni N, Alias N. Biological processes of heavy metals-contaminated environmental remediation: a review. J Environ Treat Tech 2020;9(3):601-8.

15. Jaishankar M, Tseten T, Anbalagan N, Mathew BB, Beeregowda $\mathrm{KN}$. Toxicity, mechanism and health effects of some heavy metals Interdiscip Toxicol 2014;7:60-72.
16. Naik MM, Khanolkar DS, Dubey SK. Lead resistant Providentia alcalifaciens strain 2EA bioprecipitates $\mathrm{Pb}^{2+}$ as lead phosphate. Lett Appl Microbiol 2013;56:99-104.

17. Yang T, Chen M, Wang J. Genetic and chemical modification of cells for selective separation and analysis of heavy metals of biological or environmental significance. Trends Analyt Chem 2015;66:90-102.

18. Iravani S, Varma RS. Bacteria in heavy metal remediation and nanoparticle biosynthesis. ACS Sustain Chem Eng 2020;8(14):5395409.

19. Ayangbenro AS, Babalola OO. A new strategy for heavy metal polluted environments: a review of microbial biosorbents. Int J Environ Res Public Health 2017;14(1):94.

20. Igiri BE, Okoduwa SI, Idoko GO, Akabuogu EP, Adeyi AO, Ejiogu IK Toxicity and bioremediation of heavy metals contaminated ecosystem from tannery wastewater: a review. J Toxicol 2018;2018:1-16.

21. Carolin CF, Kumar PS, Saravanan A, Joshiba GJ, Naushad M. Efficient techniques for the removal of toxic heavy metals from aquatic environment: a review. J Environ Chem Eng 2017;5(3):2782-99.

22. Gabr RM, Hassan SHA, Shoreit AAM. Biosorption of lead and nickel by living and non-living cells of Pseudomonas aeruginosa ASU 6a. Int Biodeterior Biodegr 2008;62(2):195-203.

23. Mwandira W, Nakashima K, Kawasaki S, Arabelo A, Banda K, Nyambe I, et al. Biosorption of $\mathrm{Pb}$ (II) and $\mathrm{Zn}$ (II) from aqueous solution by Oceanobacillus profundus isolated from an abandoned mine. Sci Rep 2020;10(1):1-9.

24. Munoz AJ, Espinola F, Moya M, Ruiz E. Biosorption of $\mathrm{Pb}$ (II) ions by Klebsiella sp. $3 S 1$ isolated from a wastewater treatment plant: kinetics and mechanisms studies. BioMed Res Int 2015;4:1-12.

25. Cabuk A, Akar T, Tunali S, Gedikli S. Biosorption of $\mathrm{Pb}$ (II) by industrial strain of Saccharomyces cerevisiae immobilized on the biomatrix of cone biomass of Pinus nigra: equilibrium and mechanism analysis. Chem Eng J 2207;131:293-300.

26. Burakov AE, Galunin EV, Burakova IV, Kucherova AE, Agarwal S, Tkachev AG, et al. Adsorption of heavy metals on conventional and nanostructured materials for wastewater treatment purposes: a review. Ecotoxicol Environ Saf 2018;148:702-12.

27. Mosa KA, Saadoun I, Kumar K, Helmy M, Dhankher OP. Potential biotechnological strategies for the cleanup of heavy metals and metalloids. Front Plant Sci 2016;7:303.

28. Murthy S, Bali G, Sarangi SK. Effect of lead on metallothionein concentration in lead resistant bacteria Bacillus cereus isolated from industrial effluent. Afr J Biotechnol 2011;10(71):15966-72.

29. Naik MM, Pandey A, Dubey SK. Biological characterization of leadenhanced exopolysaccharide produced by a lead resistant Enterobacter cloacae strain P2B. Biodegradation 2012;23(5):775-83.

30. Utami U, Harianie L, Dunyana NR, Romaidi R. Lead-resistant bacteria isolated from oil wastewater sample for bioremediation of lead. Water Sci Technol 2020;81(10):2244-9.

31. Saleem M, Asghar HN, Ahmad W, Akram MA, Saleem MU, Khan MY, et al. Prospects of bacterial-assisted remediation of metalcontaminated soils. Agro-Environ Sustainability 2017:41-58.

32. Naik MM, Khanolkar DS, Dubey SK. Lead resistant Providentia alcalifaciens strain 2EA bioprecipitates $\mathrm{Pb}^{2+}$ as lead phosphate. Let Appl Microbiol 2013;56:99-104.

33. Qian X, Fang C, Huang M, Achal V. Characterization of fungalmediated carbonate precipitation in the biomineralization of chromate and lead from an aqueous solution and soil. J Clean. Prod 2017;164:198-208.

34. Chen Z, Pan X, Chen H, Guan X, Lin Z. Biomineralization of Pb (II) into $\mathrm{Pb}$-hydroxyapatite induced by Bacillus cereus 12-2 isolated from lead-zinc mine tailings. J Hazard Mater 2016;301:531-7.

35. Park JH, Bolan N, Meghraj M, Naidu N. Concomitant rock phosphate dissolution and lead immobilization by phosphate solubilizing bacteria (Enterobacter sp.). J Environ Manage 2011;92:1115-20.

36. Shin MN, Shim J, You Y, Myung H, Bang KS, Cho M, et al Characterization of lead resistant endophytic Bacillus sp. MN3- 
4 and its potential for promoting lead accumulation in metal hyperaccumulator Alnus firma. J Hazard Mater 2012;199:314-20.

37. Zhou Y, Cui Y, Qu X. Exopolysaccharides of lactic acid bacteria: structure, bioactivity and associations: a review. Carbohydr Polym 2019;207:317-32.

38. Raungsomboon S, Chidthaisong A, Bunnag B, Inthorn D, Harvey NW. Production, composition and $\mathrm{Pb}^{2+}$ adsorption characteristics of capsular polysaccharides extracted from a cyanobacterium Gloeocapsa gelatinosa. Water Res 2006;40(20):3759-66.

39. Amoozegar MA, Ghazanfari N, Didari M. Lead and cadmium bioremoval by Halomonas sp., an exopolysaccharide-producing halophilic bacterium. Prog Biol Sci 2012;2(1):1-11.

40. Zulfiqar U, Farooq M, Hussain S, Maqsood M, Hussain M, Ishfaq $\mathrm{M}$, et al. Lead toxicity in plants: impacts and remediation. J Environ Manage 2019;250:109557.

41. Gupta P, Diwan B. Bacterial exopolysaccharide mediated heavy metal removal: a review on biosynthesis, mechanism and remediation strategies. Biotechnol Rep 2017;13:58-71.

42. Templeton AS, Trainor TP, Spormann AM, Newville M, Sutton $\mathrm{SR}$, Dohnalkova A, et al. Sorption versus biomineralization of $\mathrm{Pb}$ (II) within Burkholderia cepacia biofilms. Environ Sci Technol 2003;37(2):300-7.

43. Xie B, Gu JD, Li XY. Protein profiles of extracellular polymeric substances and activated sludge in a membrane biological reactor by 2-dimensional gel electrophoresis. Water Sci Technol Water Supply 2006;6(6):27-33

44. Sag Y, Tatar B, Kutsal T. Biosorption of $\mathrm{Pb}$ (II) and $\mathrm{Cu}$ (II) by activated sludge in batch and continuous-flow stirred reactors. Bioresour Technol 2003;87(1):27-33.

45. Khulbe KC, Matsuura T. Removal of heavy metals and pollutants by membrane adsorption techniques. Appl Water Sci 2018;8(1):1-30.

46. Joutey NT, Sayel H, Bahafid W, El Ghachtouli N. Mechanisms of hexavalent chromium resistance and removal by microorganisms. Rev Environ Contam Toxicol 2015;233:45-69.

47. Joseph L, Jun BM, Flora JR, Park CM, Yoon Y. Removal of heavy metals from water sources in the developing world using low-cost materials: a review. Chemosphere 2019;229:142-59.

48. Jacob JM, Karthik C, Saratale RG, Kumar SS, Prabakar D, Kadirvelu $\mathrm{K}$, et al. Biological approaches to tackle heavy metal pollution: a survey of literature. J Environ Manage 2018;217:56-70.

49. Chandrangsu P, Rensing C, Helmann JD. Metal homeostasis and resistance in bacteria. Nat Rev Microbiol 2017;15(6):338-50.

50. Borremans B, Hobman JL, Provoost A, Brown NL, van Der Lelie D. Cloning and functional analysis of the $p b r$ lead resistance determinant of Ralstonia metallidurans CH34. J Bacteriol 2001;183(19):5651-8.

51. Karkman A, Do TT, Walsh F, Virta MP. Antibiotic-resistance genes in waste water. Trends Microbiol 2018;26(3):220-8.

52. Hynninen PH, Kaartinen V, Kolehmainen E. Horseradish peroxidasecatalyzed oxidation of chlorophyll a with hydrogen peroxide: characterization of the products and mechanism of the reaction. Biochim Biophys Acta 2010;1797:531-42.

53. Ibrahim HM. Biodegradation of used engine oil by novel strains of Ochrobactrum anthropi HM-1 and Citrobacter freundii HM-2 isolated from oil-contaminated soil. 3 Biotech 2016;(2):1-3.

54. Mwandira W, Nakashima K, Kawasaki S. Bioremediation of leadcontaminated mine waste by Pararhodobacter $s p$. based on the microbially induced calcium carbonate precipitation technique and its effects on strength of coarse and fine grained sand. Ecol Eng 2017;109:57-64.

55. Mugwar AJ, Harbottle MJ. Toxicity effects on metal sequestration by microbially-induced carbonate precipitation. J Hazard Mater 2016;314:237-48.

56. Li X, Peng W, Jia Y, Lu L, Fan W. Bioremediation of lead contaminated soil with Rhodobacter sphaeroides. Chemosphere 2016;156:228-35.

57. Liu SH, Zeng GM, Niu QY, Liu Y, Zhou L, Jiang LH, et al. Bioremediation mechanisms of combined pollution of PAHs and heavy metals by bacteria and fungi: a mini review. Bioresour Technol 2017;224:25-33.

58. Saha M, Sarkar S, Sarkar B, Sharma BK, Bhattacharjee S, Tribedi P. Microbial siderophores and their potential applications: a review. Environ Sci Pollut Res 2016;23(5):3984-99.

59. Liu J, Chen X, Shu HY, Lin XR, Zhou QX, Bramryd T, Shu WS, Huang LN. Microbial community structure and function in sediments from e-waste contaminated rivers at Guiyu area of China. Environ Pollut 2018;235:171-9.

60. Sharma P. Efficiency of bacteria and bacterial assisted phytoremediation of heavy metals: an update. Bioresour Technol 2021:124835.

61. Medfu Tarekegn M, Zewdu Salilih F, Ishetu AI. Microbes used as a tool for bioremediation of heavy metal from the environment. Cogent Food Agric 2020;6(1):1783174.

62. Zamel D, Hassanin AH, Ellethy R, Singer G, Abdelmoneim A. Novel bacteria-immobilized cellulose acetate/poly (ethylene oxide) nanofibrous membrane for wastewater treatment. Sci Rep 2019;9(1):1-1.

63. Celebioglu A, Topuz F, Yildiz ZI, Uyar T. Efficient removal of polycyclic aromatic hydrocarbons and heavy metals from water by electrospun nanofibrous polycyclodextrin membranes. ACS Omega 2019;4(4):7850-60.

64. Kamal A, Ahmad F, Shafeeque M. Toxicity of pesticides to plants and non-target organism: A comprehensive review. Iranian J Plant Physiol 2020;10(4):3299-313.

65. Xu Z, Lei Y, Patel J. Bioremediation of soluble heavy metals with recombinant Caulobacter crescentus. Bioeng Bugs 2010;1(3):207-12.

66. Wei W, Zhu T, Wang Y, Yang H, Hao Z, Chen PR, et al. Engineering a gold-specific regulon for cell-based visual detection and recovery of gold. Chem Sci 2012;3:1780-84.

67. Jafarian V, Ghaffari F. A unique metallothionein-engineered in Escherichia coli for biosorption of lead, zinc, and cadmium; absorption or adsorption? Microbiology 2017;86:73-81.

How to cite this article:

Shahid A, Pandey C, Ahmad F, Kamal A. Bacterial bioremediation: Strategies adopted by microbial-community to remediate lead from the environment. J Appl Biol Biotech 2021; 9(06):18-24. 